\title{
Significant increase in the incidence of high-risk pulmonary embolism during the COVID-19 shutdown: the pandemic response causes serious collateral consequences
}

Research

Keywords:

Posted Date: September 30th, 2020

DOl: https://doi.org/10.21203/rs.3.rs-46099/v2

License: (1) This work is licensed under a Creative Commons Attribution 4.0 International License. Read Full License

Version of Record: A version of this preprint was published at European Journal of Internal Medicine on December 1st, 2020. See the published version at https://doi.org/10.1016/j.ejim.2020.10.007. 


\section{Abstract}

The authors have requested that this preprint be withdrawn due to author disagreement.

\section{Full Text}

The authors have withdrawn this preprint from Research Square. 